\title{
Clientearth (No. 2): A CaSe OF Three Legal Dimensions
}

\author{
Joanna Bell*
}

\section{INTRODUCTION}

ClientEarth (No. 2) v Secretary of State for the Environment, Food and Rural Affairs ${ }^{1}$ is the latest stage in the legal saga concerning the UK Government's continuing breach of the 2008/50/EC Air Quality Directive. ${ }^{2}$ The case is centred on the lawfulness of the Government's latest Air Quality Plan, a document published in December 2015, which lays out the current plans for ensuring that levels of nitrogen dioxide across the UK are reduced to lawful levels. The non-governmental organisation, ClientEarth sought to argue that a number of flaws in the approach to 'air quality modelling' ${ }^{3}$ used by the Government in the production of this Air Quality Plan rendered it unlawful. Garnham J, the judge in the High Court who heard the case, accepted ClientEarth's arguments, ultimately issuing an order requiring that the Government produce a new Air Quality Plan by April 2017. ${ }^{4}$

This analysis has two main purposes. The first is to show that ClientEarth (No. 2) is a case of three legal dimensions. What this means is that three distinct sets of legal concerns play an important role in both the applicant's arguments and Garnham J's reasoning. These related first, to environmental modelling, second, to European Union (EU) law and, third, to domestic judicial review. The first purpose of this analysis is to draw attention to these three legal dimensions and to discuss the role played by each in how the court reached its conclusion.

Following from this, the second objective is to reflect on these dimensions, focusing in particular on environmental modelling and domestic judicial review. In relation environmental modelling, it is useful to consider the role that judges play in scrutinising such processes. As will be shown, there has been a tendency on the part of judges to speak of environmental modelling as a field of public decision-making in relation to which it is appropriate to take a highly deferential approach to scrutiny. This analysis, explains why, in my view, although ClientEarth (No. 2) does not mark a sea-change in the approach towards a rigorous approach to scrutiny across the board, it does suggest that the courts will intensify scrutiny when the legislative context demands it.

In relation to domestic judicial review, it is helpful to consider the role the grounds of error of law and irrelevant considerations played in the legal reasoning in ClientEarth (No. 2). My argument is that the usefulness of these grounds lay in the provision of a legal framework around which the applicant's argument and the court's conclusions could be organised. This is interesting from two perspectives. From an administrative law perspective, it is a reminder that

\footnotetext{
* Lecturer and Fellow, St John's College, Cambridge. (jrb222@cam.ac.uk)

${ }^{1}$ ClientEarth (No. 2) v Secretary of State for the Environment, Food and Rural Affairs [2016] EWHC 2740 (Admin). ('Clientearth no 2').

${ }^{2}$ Directive 2008/50/EC of the European Parliament and of the Council of 21 May 2008 on ambient air quality and cleaner air for Europe ('Air Quality Directive').

3 ibid [59].

${ }^{4} R$ (ClientEarth) v Secretary of State for Environment, Food and Rural Affairs, unreported (21 Nov 2016).
} 
the concept of a 'ground' of judicial review is not monistic; different grounds play different roles in legal reasoning and interact differently with legislation. From an environmental law perspective, it is an illustration of the utility of the domestic grounds of judicial review in providing a recognisable legal structure over which difficult, and novel, legal arguments can be draped. There are, accordingly, a considerable number of reasons why ClientEarth (No 2) is an important case worthy of analysis.

\section{BACKGROUND}

Before turning to ClientEarth (No 2) itself it is useful to first provide two important aspects of the background to the case. First, it is helpful to briefly outline the background legal framework and, in particular, the Air Quality Directive. ${ }^{5}$ The EU has long held a commitment to improving the quality of ambient air within Member States with the goal, in turn, of lessening the impact of climate change, ozone depletion and acidification. ${ }^{6}$ In light of this commitment, in 2005 the Commission announced a major new Thematic Strategy on Air Pollution, ${ }^{7}$ the aims of which include the prevention of 'thousands of premature deaths from pollution-related illnesses ${ }^{8}$ and the drastic reduction of 'damages to crops, forests and other ecosystems. ${ }^{9}$ Part of the strategy included an overhaul of existing legislation for the purposes of improvement and simplification. The product of this part of the strategy was the Air Quality Directive. Much could be said of this Directive, ${ }^{10}$ however, for the purposes of understanding ClientEarth (No. 2 ) it is only necessary to discuss two of its key provisions.

First, Article 13 of the Directive affirms ${ }^{11}$ an obligation on the part of Member States to reduce the quantity of nitrogen dioxide present in ambient air below a specified level. ${ }^{12}$ The date stipulated for fulfilment of this obligation was 1 January $2010 .{ }^{13}$ Second, in the event of a Member State failing to fulfil this obligation by the stipulated deadline, Article 23 of the Directive places Member States under a further obligation to produce an 'Air Quality Plan.' 14 Importantly, Article 23 requires that the content of such a plan must 'set out appropriate measures, so that the exceedance period can be kept as short as possible."15

The second important piece of background information is the Supreme Court's decision in $R$ (ClientEarth) v Secretary of State for the Environment, Food \& Rural Affairs [2015]

\footnotetext{
${ }^{5}$ Air Quality Directive (n 2).

6 See in particular European Commission, 'EU Focus on Clean Air', available at http://ec.europa.eu/environment/archives/eufocus/clean_air.pdf (last accessed 29th March 2017).

${ }^{7}$ Press release available at http://europa.eu/rapid/press-release IP-05-1170_en.htm?locale=fr $\left(\right.$ last accessed $29^{\text {th }}$ March 2017).

8 ibid.

9 ibid.

${ }^{10}$ See, for example, Mark Wilde, 'The New Directive on Ambient Air Quality and Cleaner Air for Europe' (2010) 12 Env LR 282.

11 Air Quality Directive was preceded by Directive 1999/30/EC of 22 April 1999 relating to limit values for sulphur dioxide, nitrogen dioxide and oxides of nitrogen, particulate matter and lead in ambient air, which first recognised this obligation, and Council Directive 96/62/EC of 27 September 1996 on ambient air quality assessment and management.

${ }^{12}$ Article 13 Air Quality Directive (n 2). The specified level can be found Annexe XI to the Directive.

13 ibid, Annexe XI.

${ }^{14}$ Defined in Article 2, ibid. Details of what is to be included in an Air Quality Plan can be found in Annex XV to the Directive.

${ }^{15}$ Article 23, ibid (emphasis added).
} 
UKSC 28. ${ }^{16}$ In this case, the Supreme Court recognised that the Government, in failing to reduce nitrogen dioxide below the specified level for a number of 'zones' and 'agglomerations ${ }^{17}$ within the UK, was in continuous breach of its core obligation under Article 13 of the Air Quality Directive. ${ }^{18}$ Accordingly the Supreme Court concluded the Government was obligated to produce an Air Quality Plan in accordance with the terms of Article $23 .{ }^{19} \mathrm{~A}$ mandatory order was thus issued 'requiring the Secretary of State to prepare new air quality plans under Article 23. ${ }^{20}$ The date specified for the production of these plans was 31 December 2015. The Government published its new Air Quality Plan on 17 December $2015 .{ }^{21}$ It was the lawfulness of this plan, which was the central issue in ClientEarth (No. 2). ${ }^{22}$

\section{A CASE OF THREE LEGAL DIMENSIONS}

As noted above, the first point that this analysis sets out to make is that the applicant's arguments and judge's reasoning in ClientEarth (No. 2) have three distinct, though closely related, legal dimensions. Though it somewhat defies the chronology of the judgment, it is helpful to begin with the environmental modelling dimension. At this level the applicant sought to argue that the approach to 'air quality modelling' ${ }^{23}$ taken by the Government in the development of its Air Quality Plan was fundamentally flawed in two central ways.

First, the Government, in developing its new Air Quality Plan, had made no adjustments to its usual modelling method. This method, which the Government had adopted 'as a matter of routine for a number of years ${ }^{24}$ partly on the basis that it was generally used by the European Commission, ${ }^{25}$ generated projections on a five-yearly cycle. As a result, and given that the latest projection had related to 2015, the Government had fixed on 2020 as the year by which it would aim to achieve the reductions in nitrogen dioxide. This, ClientEarth argued, was illegitimate. ClientEarth emphasised the urgency with which steps needed to be taken meant that the Government ought to have adjusted its usual modelling approach in order to generate projections at more regular intervals. Furthermore, there was some suggestion in the case that this could have been done for a 'relatively modest cost' ${ }^{26}$ but that the government had opted not to switch models for reasons of administrative convenience. ${ }^{27}$ The second flaw in the government's modelling methods to which ClientEarth pointed was the use of overly optimistic estimates. The Government, in particular, had made use of a particular set of estimates, known

\footnotetext{
${ }^{16} R$ (ClientEarth) $v$ Secretary of State for the Environment, Food \& Rural Affairs [2015] UKSC 28. For discussion see for example Richard Moules, 'Air Quality' (2016) 28(1) JEL 171; James Thornton, 'Can We Catch Up? How the UK is Falling Behind on Environmental Law' (2016) 92 Env Law 38.

${ }^{17}$ Terms defined in Article 2, Air Quality Directive (n 2).

${ }^{18}$ ClientEarth (n 16), [29]-[30].

19 ibid, [24].

20 ibid, [35].

${ }^{21}$ ClientEarth (No 2) (n 1), [4].

${ }^{22}$ Note that much more could be said on the background to this case which is the latest in an extensive line of cases. See further especially $R$ (ClientEarth) $v$ Secretary of State for the Environment, Food \& Rural Affairs [2013] UKSC 25, [2013] 3 CMLR 29; $R$ (ClientEarth) v Secretary of State for the Environment, Food \& Rural Affairs (C-404/13), [2015] 1 CMLR 55.

${ }^{23}$ ibid, [59].

24 ibid, [57].

25 ibid.

26 ibid, [61]. See also [58].

27 ibid, [73].
} 
as the 'COPERT' estimates, ${ }^{28}$ of the quantity of nitrogen dioxide emitted by diesel vehicles when it was commonly thought that such vehicles emitted a considerably greater quantity than the estimates suggested. ${ }^{29}$ Garnham $\mathrm{J}$ agreed that both of these flaws rendered the Government's Air Quality Plan unlawful. ${ }^{30}$

The second, EU law dimension of the applicant's argument consisted in the allegation that the government, in developing its Air Quality Plan, had acted contrary to Article 23 of the Air Quality Directive. ${ }^{31}$ In particular, ClientEarth argued that the various flaws in the Government's approach to modelling meant that it had failed to comply with the requirement in Article 23 that set out measures that will ensure 'that the exceedance period can be kept as short as possible ${ }^{32}$ Thus, by failing to move to a modelling approach which would generate projections on a more regular basis the government had arbitrarily settled on 2020 when it could very well have identified measures capable of achieving the reduction more quickly. Similarly, the Government's use of the misleading COPERT estimates created an undue risk that its calculations as to the effectiveness of measures were inaccurate.

Closely related to this EU law dimension of ClientEarth's argument was a third, domestic judicial review dimension. At this level, the applicant's case amounted to the assertion that the Government had failed to comply, in developing its Air Quality Plan, with certain domestic grounds of judicial review. Two such grounds played a particularly important role in the course of ClientEarth's argument. The first ground is the error of law. Thus at points, ClientEarth's complaint is expressed as being that the Government, in continuing to make use of a modelling approach based on a five-yearly cycle, had 'erred in law in [its] approach to the requirement of Article 23 that periods of exceedance should be kept as short as possible. ${ }^{, 33}$ The second ground raised is the consideration of an irrelevant factor. As such, at other points in the case the applicant's argument is presented as being that, in failing to adjust its modelling approach, the Government had unduly taken account of 'considerations of cost, political sensitivity and administrative difficulties', ${ }^{34}$ which were 'of secondary importance to the Directive's primary purpose of protecting human health. ${ }^{, 35}$

In approaching these EU law and domestic judicial review dimensions of the applicant's case, Garnham J gave close consideration to the meaning of Article 23. He emphasised, in particular, three propositions, which he took to be explicit or implicit in the terms of this Article. First, that Article 23 confers on Member States an element of 'discretion' 36 in the selection of measures included in an Air Quality Plan but that this discretion is 'narrow and greatly constrained. ${ }^{37}$ In particular, Garnham J stressed that Member States' choices are limited by the overarching requirement of ensuring 'that the plans are devised in such a way as

28 'Computer Programme to Calculate Emissions from Road Transport'' ibid [27].

${ }^{29}$ ibid, [76]-[77]. Indeed, the known inaccuracy of these estimates was referred to by the Supreme Court in ClientEarth (n X), [21].

30 ibid [69] and [85].

${ }^{31}$ See for example ibid [5].

${ }^{32}$ Air Quality Directive (n 2), Article 13 (my emphasis). See also Regulation 26 of the Air Quality Standards Regulations (2010/1001) pls provide full ref which implements this requirement into domestic law.

${ }^{33}$ ClientEarth (No 2) (n 1), [38] (my emphasis).

34 ibid.

$35 \mathrm{ibid}$.

36 ibid [46].

37 ibid. 
to meet the limit value in the shortest possible time. ${ }^{38}$ Second, that while there may be circumstances in which a Member State may legitimately take into account considerations of cost in the formulation of an Air Quality Plan (such as where a Member State is choosing between two measures which will be equally effective in reducing nitrogen dioxide levels ${ }^{39}$ ), it is illegitimate for a Member State to take into account economic considerations in fixing a target date for the reduction of nitrogen dioxide. ${ }^{40}$ On the basis of these propositions, Garnham J considered that the Government's failure to make use of an approach to modelling which generated projections on a more regular basis, partly as a response to considerations of cost, ${ }^{41}$ rendered its Air Quality Plan unlawful.

A third and final proposition that Garnham $\mathrm{J}$ took to be implicit in Article 23 is a little more difficult. For Garnham J, embedded in this Article is a requirement of proportionality. This requirement he explained in the following terms: 'the measures a Member State may adopt... must be proportionate in the sense of being no more than is required to meet the target. ${ }^{42}$ There are two senses in which this statement can be understood, each corresponding to a different limb of the proportionality mechanism. ${ }^{43}$ First, Garnham $\mathrm{J}$ can be understood as invoking the 'least intrusive measure' 44 limb of proportionality. On this understanding, Garnham J's suggestion is that a measure, which makes a reduction to nitrogen dioxide levels will be deemed disproportionate if there is an equally effective, but less invasive, measure available. Second, Garnham J can be understood as invoking the final, 'balancing' 45 limb of proportionality. On this reading, it is Garnham J's suggestion that any measure which 'impact[s] adversely on... proper and reasonable interests' 46 and which does 'more than is required ${ }^{47}$ in terms of reducing levels of nitrogen dioxide below the level specified in the Air Quality Directive will be deemed to have struck an improper balance. This second reading of Article 23 is deeply problematic. If correct, it would have the unfortunate effect of precluding Member States from implementing measures, which go beyond the protections laid down by EU law. Given that there is nothing in the Directive to suggest that its intention it to tie the hands of Member States in this way, this aspect of Garnham J's judgment ought to be understood in the first sense.

To summarise, an important feature of ClientEarth (No. 2) is that the court's decision, and the applicant's argument, had three distinct legal dimensions. That is, the conclusion of the case can be expressed in terms of three different sets of legal concerns. From the perspective of environmental modelling concerns, the court's conclusion was that the Government's approach to air quality modelling was tainted by a number of fundamental flaws. From a the perspective of EU law concerns, the court's decision can be understood as being that the

\footnotetext{
38 ibid [47].

39 ibid [50].

40 ibid.

41 ibid [69].

42 ibid [51] (emphasis added).

${ }^{43}$ For helpful discussion of the proportionality method see especially Bank Mellat v HM Treasury (No 2) [2013] UKSC 39, [2014] AC 700, [74]. Note the ambiguity raised in R (Lumsdon) v Legal Services Board [2015] UKSC 41, [2016] AC 697, [33] as to whether the fourth limb of the usual proportionality method applies in the context of a challenge based on EU law.

${ }^{44}$ Bank Mellat (n 43), [74].

45 ibid.

${ }^{46}$ ClientEarth (No 2) (n 1), [51].

47 ibid.
} 
Government, in developing its Air Quality Plan, had failed to comply with the Article 23 requirement that such plans include measures designed to ensure that the 'exceedance period... be kept as short as possible. ${ }^{48}$ Finally, from the perspective of domestic judicial review concerns the court's conclusion was that the Government made an error of law in relation to the meaning of Article 23 and had taken account of irrelevant considerations of cost in setting its target date for realising reductions in nitrogen dioxide.

In the final parts of this study, this analysis will be further developed. It will focus in particular, on the environmental modelling and domestic judicial review dimensions in relation to which, in my view, the case is of considerable interest. Before turning to these reflections, however, a more general point can be made about the significance of ClientEarth (No. 2): the case is a clear illustration of the multi-dimensional nature of EU environmental law. It is a reminder that a judge, in hearing a case within this field, must navigate many overlapping layers of argument and, in reaching a conclusion, must seek to weave together strands taken from various sources.

\section{ENVIRONMENTAL MODELLING DIMENSION: HOW RIGOROUSLY WILL JUDGES SCRUTINISE ENVIRONMENTAL MODELS?}

In relation to the environmental modelling dimension, the question which ClientEarth (no. 2) raises is the following: what role will the judiciary play in scrutinising the environmental modelling processes deployed by executive bodies? In exploring this question, and the contribution made by the case, it is helpful to begin with the following passage from Collins J's judgment in the High Court in Downs ${ }^{49}$ - a case which was in part concerned with a challenge to a bystander pesticide-exposure model:

There are conflicting views as to the adequacy of the [modelling] approach adopted... I am not qualified to decide between those views nor is it an appropriate exercise for a judge to undertake on judicial review. No doubt if it were clear that one view was tainted by irrationality in the Wednesbury sense, the court could so declare. But that is most unlikely to be established and, as it seems to me, we are here at the very fringe of what should properly be the subject of judicial review. ${ }^{50}$

Embedded in this passage is a clear understanding of the role of the judiciary in the scrutiny of environmental modelling processes. According to this understanding, modelling falls squarely within the relative expertise of the executive and, accordingly, the judiciary's role in scrutinising such models should be very light touch. The proper approach for a court, then, is to intervene only when the executive's approach to modelling contains an error, which renders it unreasonable in the strict Wednesbury sense. ${ }^{51}$

\footnotetext{
${ }^{48}$ Air Quality Directive (n X), Article 23.

${ }^{49}$ Downs v Secretary of State for Environment, Food and Rural Affairs [2008] EWHC 2666 (Admin), [2009] Env LR 19. Note that the High Court ultimately found for the applicant, a decision which was subsequently overturned by the Court of Appeal in [2009] EWCA Civ 664, [2009] 3 CMLR 46.

50 ibid [38].

${ }^{51}$ Associated Provincial Picture Houses Ltd v Wednesbury Corporation [1948] 1 KB 223 (CA), 230.
} 
This way of thinking about the role of the judiciary in the scrutiny of environmental models, characterised as it is by a high level of deference, is not confined to the Downs case. In fact, Elizabeth Fisher, Wendy Wagner and Pasky Pascual ${ }^{52}$ have noted that there is a general tendency on the part of judges in similar cases to "stress their lack of competence and the importance of deference to expert discretion. ${ }^{53}$ This is a tendency, the authors suggest, which is connected to a prevalent perception of such models as being inherently 'scientific' 54 and consisting of "a "thick of formulae and computer codes" that require specialist knowledge to navigate'. ${ }^{55}$ As a result, it is thought to being 'too much part of what occurs in the back office of administrative practice ${ }^{56}$ to be a subject of meaningful engagement by lawyers.

Against this background, two points are particularly striking about Garnham J's judgment in ClientEarth (No. 2). First, the high level of confidence with which the judge sets about scrutinising the Government's environmental modelling approach and second, the relatively low level of error at which the judge intervenes. Thus, Garnham J's judgment contains none of the customary references to the importance of deference, which Fisher et al suggest are traditionally characteristic of judicial decisions in this area. Relatedly, the 'errors' which Garnham $\mathbf{J}$ identifies in the Government's modelling approach probably fall short of being 'so unreasonable that no reasonable authority' 57 would make them. This seems particularly true of the government's use of the diesel vehicle emission estimates, which, the government argued, were 'industry recognised standards' 58 'used by most Member States across the EU. ${ }^{59}$

Does ClientEarth (No. 2) then mark some kind of transformation of the judicial approach to the scrutiny of environmental modelling? Might we expect to see this rigorousness of scrutiny reflected in all further cases? My view is that it does not. It is important, in particular, to bear in mind the particular legislative and regulatory backdrop to ClientEarth (No. 2). The case is set against both a legal obligation to reduce nitrogen dioxide levels of which the Government is in continuing breach and a clear quasi-remedial obligation on the part of the Government to take steps to ensure that the exceedance period is kept 'as short as possible. ${ }^{60}$ The most likely explanation of Garnham J's rigorous approach to scrutiny in ClienthEarth (No. 2 ) is not that we are seeing a sea-change whereby the judiciary now feel more comfortable occupying a scrutiny role. It is rather that the relevant legal obligations engaged in the case were thought to necessitate a rigorous testing of whether the government's response demonstrated a serious commitment to meeting these targets.

This same point can be expressed in two different ways. One the one hand, and viewed narrowly, the interest of ClientEarth (No. 2) lies not in what it shows about the judiciary's general approach to the scrutiny of models but in what it shows about the judiciary's specific

\footnotetext{
${ }^{52}$ Elizabeth Fisher, Pasky Pascual \& Wendy Wagner, 'Understanding Environmental Models in their Legal and Regulatory Context' (2010) 22(2) JEL 251.

53 ibid [259].

${ }^{54}$ ibid [263].

55 ibid, [263-264] citing Jerry Ravetz, 'Models as Metaphors' in Bernd Kasemir \& Others (eds), Public Participation in Sustainability Science: A Handbook (CUP 2003), 70.

56 ibid [264].

${ }^{57}$ Associated Provincial Picture Houses Ltd v Wednesbury Corporation [1948] 1 KB 223 (CA), 229.

${ }^{58}$ ClientEarth (No 2) (n 1), [78].

${ }^{59} \mathrm{ibid}$

${ }^{60}$ Article 23, Air Quality Directive (n 2).
} 
approach to scrutiny under Article 23 of the Air Quality Directive. Imagine, for instance, that the Government makes a voluntary commitment to reducing the quantity of nitrogen dioxide to a level considerably lower than that stipulated in the Air Quality Directive. An applicant initiates judicial review proceedings arguing that the Government's use of a particular set of estimates in the production of an environmental model was unreasonable. Might we expect the reviewing court to exercise the same rigour in scrutinising the Government's choice of estimates as Garnham J did in ClientEarth (No. 2)? It seems clear that we ought not; in all likelihood, a court would regard a reasonableness challenge as demanding a much less rigorous approach to scrutiny than one grounded substantially in the allegation that the government had failed to fulfil a clear obligation under EU law.

On the other hand, and putting this same point more broadly, we might say the following: if there was ever a concern that the phrase 'environmental modelling' was thought of by judges as an automatic trigger for a highly deferential approach to scrutiny ClientEarth (No. 2) may go some way to alleviating those concerns. There are arguably certain phrases, which have operated in this way in UK law. Questions of 'national security,' for instance, have been said to require the accordance of 'great weight' ${ }^{\prime}$ to the government's judgment ${ }^{62}$ and it has been said that decisions about 'public expenditure' ought to be reviewed only against a 'manifest absurdity' standard. ${ }^{63}$ What ClientEarth (No. 2) tends to suggest, however, is that, when it comes to matters of environmental modelling, the judiciary takes a much more contextsensitive approach, paying close attention, in particular, to the relevant legislative and regulatory scheme and allowing this scheme to shape its approach to scrutiny.

\section{THE DOMESTIC JUDICIAL REVIEW DIMENSION: 'GROUNDS' AS A LEGAL FRAMEWORK FOR ORGANISING LEGAL ARGUMENTS}

In relation to the domestic judicial review dimension, it is important to reflect on the role that the two grounds of review - the error of law and irrelevant considerations -played in the applicant's argument and the court's reasoning in the case. It is my suggestion that doing so offers two important insights. First, that grounds of judicial review play a number of different roles in legal reasoning. Second, grounds of review may provide a useful legal structure around which difficult arguments of environmental law can be draped.

My view is that the two grounds of review - error of law and irrelevant considerations can be seen to have played a particular role in counsels' argument and the court's reasoning in ClientEarth (No. 2). These grounds, in particular, provided a legal framework around which the applicant's arguments and the court's judgment were organised. What I mean by this is the following. The applicant's argument, and the court's judgment, was grounded in the Government's alleged breach of the 'as short as possible' requirement of the Article 23 of the Air Quality Directive. The role played by the concepts of error of law and irrelevant considerations was that of providing a legal structure around which these arguments and conclusions could be arranged and presented in a clearly recognisable legal form. Thus the conclusion that the government had 'erred in law in [its] approach' ${ }^{64}$ to Article 23 was simply

\footnotetext{
${ }^{61}$ A v Secretary of State for the Home Department [2005] 2 AC 68 (HL), [29].

${ }^{62}$ See also for example Civil Service Unions v Minister for the Civil Service [1985] AC 374 (HL).

${ }^{63} R v$ Secretary of State for the Environment, ex parte Hammersmith \& Fulham LBC [1991] 1 AC 521, 597.

${ }^{64}$ ClientEarth (No 2) (n 1), [38] (my emphasis).
} 
a way of framing the court's conclusion that the Government had failed to comply with the legal requirements therein. Similarly, the applicant's argument that the Government had acted on irrelevant considerations of cost and administrative convenience was another way of framing the argument that the government had failed to fulfil its legal duty to identify the measures which would ensure that the exceedance period is kept 'as short as possible.'

This is significant in two ways. First and from an administrative law perspective it raises the important question of whether this is the role played by grounds of review in all cases? Clearly, this is not the case. In particular, there seem to be at least two further, more substantive, roles grounds of review can play legal reasoning. First, a ground of review may function as a freestanding source of unlawfulness. That is, as a legal standard to which an applicant may point in order to make the argument that a public authority had acted unlawfully. The doctrine of legitimate expectations may be thought of as a ground of judicial review which functions in this way. ${ }^{65}$ Thus, it might be said of this doctrine, that it serves as a freestanding source of unlawfulness to which applicants may point to in order to argue that a failure to deliver the content of an assurance is unlawful. ${ }^{66}$ Second, it seems possible that certain grounds of review may function as principles of statutory construction. According to this understanding, the role played by a ground is that of providing substantive interpretive guidance to a judge by offering instruction as to how to resolve an ambiguity in legislation, which is, in some sense, silent on an issue. Take, for instance, the so-called 'principle of legality. ${ }^{67}$ A conventional understanding of this principle sees it as providing interpretive guidance to judges by instructing them to adopt a particular reading when legislation is capable both of being read in ways, which are compatible and incompatible with fundamental rights.

As a result, from an administrative law perspective, ClientEarth (No. 2) is not an illustration of the function played by domestic grounds of judicial review, centrally because there is simply no such thing. It is, rather, a reminder that judicial review is both complex and varied. What the preceding analysis shows is that the concept of a 'ground' of review is not monistic; 'grounds' may be of different natures, they may play different roles in legal reasoning and they may interact with legislative and regulatory schemes in different ways. ClientEarth (No 2) is a nice illustration of one of the possible roles a ground may play: the provision of a legal framework for organising arguments based on the terms of a legislative or regulatory scheme, but this is far from the only role.

It is also important to look at the role played by the error of law and irrelevant considerations ground in ClientEarth (No 2) from an environmental law perspective. The case is a useful illustration of the utility of these legal mechanisms in providing a recognisable legal structure around which difficult and novel arguments of environmental law can be arranged. Take, for instance, ClientEarth's argument that the Government had acted unlawfully in continuing to generate predictions on a five-yearly cycle. In a sense, this was a difficult and legal novel argument to advance in that there was no obvious case law to which ClientEarth could point demonstrating the appropriateness of judicial intervention on such matters. The

\footnotetext{
${ }^{65}$ See generally Joanna Bell, 'The Doctrine of Legitimate Expectations: Right-Conferring or Power-Constraining Legal Standard?' [2016] PL 437.

${ }^{66}$ See for example $R v$ North \& East Devon Health Authority, ex parte Coughlan [2001] QB 213 (CA); Paponette $v$ Attorney General of Trinidad \& Tobago [2010] UKPC 32, [2012] 1 AC 1.

${ }^{67}$ See especially $R v$ Secretary of State for the Home Department, ex parte Simms [1999] 3 WLR 328 (HL), 131132.
} 
concept of irrelevant considerations, however, provided a recognisable legal structure over which that argument could be draped. This ground, in turn, seems to have played an important role in conceptually legitimising judicial intervention; it supplied a well-settled basis to which the judge could point as the legal foundation of his decision. One sense in which ClientEarth (No. 2) is important, then, is in illustrating the potential utility of the domestic grounds of judicial review in supplying established legal frameworks around which difficult and novel arguments of environmental law can be marshalled.

\section{CONCLUSION}

By way of conclusion, my argument is that there are three main ways in which ClientEarth (No. 2) is an important case worthy of close analysis. First, the case is interesting to those concerned about the Government's continuing breach of its obligations under the Air Quality Directive. The outcome of the case is that the Government has been placed under an obligation to produce a new Air Quality Plan by April 2017. ${ }^{68}$ In the course of producing this plan, the Government will be required to adjust its air quality modelling approach, to select a date earlier than 2020 for the fulfilment of its obligations to reduce levels of nitrogen dioxide and to make use of less optimistic estimates of diesel-vehicle-emissions. It should be further noted that, as of 15 February 2017, the Government has been issued by a final warning from the European Commission requiring it to take steps in relation to its continuing breach of Article 13 within two months or else face further proceedings before the Court of Justice of the EU. ${ }^{69}$

Second, ClientEarth (No. 2) calls attention to broader questions concerning the role the judiciary plays or will play in scrutinising approaches to environmental modelling. Here, I have suggested that, while ClientEarth (No. 2) does not mark a sea-change towards a generalised approach of rigorous scrutiny, it demonstrates the willingness of the judiciary to intensify scrutiny when the legislative and regulatory approach requires it. Third, and finally, the case is an important illustration of the role that certain grounds of review - here error of law and irrelevancy - may play in providing a legal framework for around which legal argument can be organised. This is important in two respects. First, it is a reminder that the concept of a 'ground' of review is not monistic. Second, it is a useful illustration of the significant role such grounds may play in providing a recognisable legal structure over which difficult and novel arguments of environmental law may be draped.

\footnotetext{
68 ClientEarth (n 4).

${ }^{69}$ Press release available at: http://europa.eu/rapid/press-release IP-17-238 en.htm (last accessed 29th March 2017).
} 